\title{
都道府県営の広域公園における指定管理者制度導入後 の植物管理実態等に関する研究
}

Study on Greenery Management of Prefectural Regional Parks after the Introduction of a Designated Administration System

\author{
李婷 ${ }^{*}$ 川崎 翼** 下村 泰彦* 加我 宏之* 増田 昇* \\ Ting Li Tsubasa KAWASAKI Yasuhiko SHIMOMURA \\ Hiroyuki KAGA Noboru MASUDA
}

\begin{abstract}
In this study, we investigated the greenery management of prefectural regional parks all over Japan in 2012, 8years after the introduction of a designated administration system, to understand how greenery of prefectural regional parks should be effectively managed under this system. Questionnaires were sent to 173 regional parks, and valid responses were obtained from 84 regional parks. According to the result, the followings were clarified. (1) The designated administrators including landscape/ gardening experts occupied $69.0 \%$ and those not including landscape/gardening experts occupied 31.0\%. (2) The designated administrators including landscape/gardening experts gave a better promotion for collaboration with resident by using flowers management and collaboration in planning and conducting nature and environmental learning programs than those not including landscape/gardening experts. (3) According to greenery maintenance, it was revealed that the designated administrators including landscape/gardening experts were highly likely to make a mid- or long-term program, including landscape formation, and accumulated technical know-how on green maintenance.

Keywords : designated administration system, regional parks, greenery management, maintenance of trees and woods, volunteer groups, resident participation

キーワード：指定管理者制度，広域公園，植物管理，樹木・樹林管理，ボランティア団体，住民参画
\end{abstract}

\section{1.はじめに}

平成 15 年に地方自治法が一部改正され，翌平成 16 年には都市 公園においても指定管理者制度が導入された。全国において平成 17 年から 18 年にかけて指定管理者への移行が大幅に進んだが, 約 8 年が経過し， 2 期目もしくは 3 期目を迎えている公園も少な くない。 2 期目あるいは 3 期目には, 民間企業や異業種の共同企 業体による指定管理事例が増加しており, 行政の外郭団体単独に よる受託から「産」（民間企業）や「民」（地域住民・NPO）の 参画が進みつつあると言える。これは, 指定管理者制度導入の目 的の一つでもある「民間の能力を活用した効率的な経営」という 視点では評価できるものの, 都市公園の特殊性ともいえる「植物 の育成管理」や「住民参画への対応」等に関連する管理運営の適 正化が課題になってきているとの指摘も認められる ${ }^{1)}$ 。

近年の指定管理者に関する既往論文を見ると, 塚田らは都市公 園に打ける指定管理者の選考基準に着目し今後の指定管理者の評 価手法の在り方を探り ${ }^{2)}$, 浦田らは新たに公園管理に参入した民 間の指定管理者と公園内で活動する市民グループとの関係を調查 し ${ }^{3}$ ，大瀧らは岩手県下の指定管理者制度が導入された 2 公園を 事例に指定管理者制度による都市公園の協働型管理運営の成果と 課題を探っている ${ }^{4)}$ 。また, 前田は指定管理者制度導入前後にお ける全国規模の利用者の満足度調査により, 利用者本位の公園管 理の視点から制度導入の影響等を探り ${ }^{5}$, , 李らは全国の都道府県 営の広域公園における制度導入の 1 期目から 2 期目への変化を調 査し, 制度導入の動向や指定管理者の選定基準についての变化を 捉えている ${ }^{6)}$ 。さらに, 李らは大阪府営公園大泉緑地を対象とし て各種の利用形態が想定される樹林地の植生特性と, その特性を 成立させている指定管理者による管理実態を把握し, 各種の利用 に適合した樹林地管理を確立させるための基礎資料を提供してい $ろ^{7)}$ が, 都市公園の特殊性ともいえる植物の育成管理（以下「植
物管理」という）と指定管理者制度導入との関係を深く論究した 論文はほとんど見られない。

本研究では, 平成 24 年に実施した都道府県営の広域公園にお ける指定管理者制度導入後の植物管理の実態等に関するアンケー 卜調査結果を，造園系団体を含む指定管理者と含まない指定管理 者に分けて分析し，指定管理者制度導入後の両者の植物管理等の 差異を明らかにすることによって, 広域公園における植物管理等 に関する造園分野の技術特性を明確化させることを目的とする。

\section{2. 研究の方法}

全国で指定管理者制度を導入している都市公園は，小規模な街 区公園から大規模公園まで見受けられるが，造園分野の役割を明 確化させるためには豊かな樹林，樹木を保有し，多様な主体の参 画が想定できる大規模公園を対象とする必要があると考えた。そ こで, 指定管理者制度が導入されている都道府県営の広域公園を 対象にアンケート調查を実施した。対象公園は 173 公園で，平成 24 年 8 月〜 9 月に各公園の指定管理者宛にアンケート用紙を郵 送するとともにメールで回答を依頼し収集した。指定管理者が複 数の団体で構成されている場合には，すべての団体が実施する植 物管理の実態等について指定管理者の代表者から回答を得た。ア ンケートの有効回答数は 84 公園, 有効回答率は $48.6 \%$ であった。 今回有効回答を得た 84 広域公園の規模別の内訳は 50 100ha 規 模のものが 39 公園と最も多く, 100ha 以上が 11 公園, 50ha 未 満が 34 公園であった。

解析では，3．（1）項で類型化した造園系団体を含む指定管 理者と含まない指定管理者別に運営管理業務の実態，植物管理の 実態及び植物管理を行う際の課題を探った。具体的には，指定管 理者構成団体の団体類型毎に運営管理業務における協働ボランティ アの参画状況を調査し，また，植物管理における業務実施主体の

\footnotetext{
${ }^{*}$ 大阪府立大学大学院生命環境科学研究科 ${ }^{* *}$ 西日本高速道路(㑣)
} 
表 -1 指定管理者構成団体の団体種別

\begin{tabular}{|l|l|c|c|}
\hline & & 回答数 & 割合 (\%) \\
\hline \multirow{5}{*}{ 造園系団体 } & 財団法人(公園管理系) & 36 & 42.9 \\
\cline { 2 - 4 } & 公社(公園管理系) & 2 & 2.4 \\
\cline { 2 - 4 } & 社団法人(造園系) & 1 & 1.2 \\
\cline { 2 - 4 } & 株式会社(造園コンサルタント系) & 4 & 4.8 \\
\cline { 2 - 4 } & 株式会社(造園施設·建設業系) & 25 & 29.8 \\
\hline \multirow{5}{*}{ 造園系以外の団体 } & 財団法人(スボーツ振興系) & 8 & 9.5 \\
\cline { 2 - 4 } & 財団法人(その他) & 3 & 3.6 \\
\cline { 2 - 4 } & 公社(その他) & 2 & 2.4 \\
\cline { 2 - 4 } & 株式会社(ビルメンテナンス系) & 9 & 10.7 \\
\cline { 2 - 4 } & 株式会社(セキュリティ系) & 1 & 1.2 \\
\cline { 2 - 4 } & 株式会社(スポーツ関連企業) & 6 & 7.1 \\
\cline { 2 - 4 } & 株式会社(その他) & 12 & 14.3 \\
\cline { 2 - 4 } & NPO法人 & 4 & 4.8 \\
\cline { 2 - 5 } & 行政(市町村) & 3 & 3.6 \\
\hline
\end{tabular}

(注) 複数の団体で構成されている指定管理者があるため, 回答数と割合 (\%)の合計は有効回答 数の回答数と割合 (\%) より大きい。

\section{表－２＼cjkstart造園系団体に着目した類型内訳}

\begin{tabular}{|c|c|c|c|}
\hline & & 回答数 & 割合 (\%) \\
\hline \multirow{4}{*}{ 造園系団体を含む } & 造園系団体の単独 & 35 & 41.7 \\
\hline & 造園系団体同士のJV & 12 & 14.3 \\
\hline & 造園系団体と造園系でない団体のJV & 11 & 13.1 \\
\hline & 小計 & 58 & 69.0 \\
\hline \multirow{3}{*}{ 造園系団体を含まない } & 造園系でない団体の単独 & 21 & 25.0 \\
\hline & 造園系でない団体同士のJV & 5 & 6.0 \\
\hline & 小計 & 26 & 31.0 \\
\hline 計 & & 84 & 100.0 \\
\hline
\end{tabular}

状況，協働ボランティアの参画状況，管理目的，管理目標像の設 定期間, 技術面の課題, 利用調整面の課題を調查し, 造園系団体 を含む指定管理者と含まない指定管理者との間で比較考察した。

なお，植物管理は樹木一本ごとに実施する樹木管理（剪定・刈 込, 施肥, 病害虫防除, 灌水など), 群植された樹林ごとに実施 する樹林管理 (下草刈, 除伐・間伐, 萌芽更新など), 芝生地に 対して実施する芝生管理（芝刈, 施肥, 目土掛け, 灌水, エアレー ションなど), 観賞のための草花を対象に実施する草花管理（花 壇管理, 野草管理など), その他の草地に対して実施する草地管 理（雑草の除去，草刚など）に区分して設問を設けた。

\section{3. 解析結果および考察}

\section{（1）指定管理者の構成団体}

指定管理者の構成団体の団体種別は表－1に示すように「造園 系団体」と「造園系以外の団体」の 2 つに分類した。さらに, 表 - 2 に示すように構成団体の組み合わせに着目し,「造園系団体を 含む」は, 「造園系団体の単独」,「造園系団体同士の共同企業体 (以後, J V ) 」,「造園系団体と造園系でない団体の J V」の 3 類型 に分類した。また，「造園系団体を含まない」は，「造園系でない 団体の単独」「造園系でない団体同士の J V」の 2 類型に分類した。

この分類で整理した結果, 表 -1 のとおり,「造園系団体」の 内訳を見ると「財団法人 (公園管理系)」が 36 者 (42.9\%) で最 屯多く, 次いで「株式会社 (造園施設・建設業系)」が 25 者 （29.8\%）と多い。「造園系以外の団体」では「株式会社（その他）」 が 12 者 (14.3\%) で最も多く, 次いで「株式会社（ビルメンテ ナンス系) が 9 者 (10.7\%), 「財団法人（スポーツ振興系)」が 8 者 (9.5\%),「株式会社（スポーツ関連企業）」が 6 者 (7.1\%) と続く。また, 表一 2 のとおり,「造園系団体を含む」が $69.0 \%$, 「造園系団体を含まない」が $31.0 \%$ となっている。構成団体の組 み合わせに着目した各類型に関しては, 「造園系団体の単独」が $41.7 \%$, 「造園系団体同士の J V」が $14.3 \%$, 「造園系団体と造園 系でない団体の J V」が $13.1 \%$, 「造園系でない団体の単独」が 25.0\%，「造園系でない団体同士の J V」が $6.0 \%$ となっている。

以上より, 団体種別では, 指定管理者制度導入以前より公園管 理に携わってきた「財団法人 (公園管理系)」が 4 割以上と多く, 依然として指定管理者の中心を担っていることが分かる。それに
続き「株式会社（造園施設・建設業系）」が約 3 割と多い。一方, 造園系以外の団体については「株式会社（その他）」や「株式会社 (ビルメンテナンス系)」がそれぞれ約 1 割等，様々な民間団体が 指定管理者として公園管理に参入していることが明らかとなった。 また, 「造園系団体の単独」が約 4 割, 「造園系でない団体の単独」 が 2 割強之, 1 団体による単独受託が半分以上を占めているものの, J V による共同受託が 3 割強発生していることから, 複数団体によ る業務の連携分担を念頭に置いた公園管理が相当あることがわかる。

なお，指定管理の期間は 5 年が $52.4 \%$ と最も多く，次いで， 3 年が $26.2 \%$ となり，指定管理期間は 5 年が主流となっていること も明らかとなった。

\section{(2) 実施体制}

\section{（i ）植物管理実施主体の状況}

植物管理実施主体の状況（図－1）を見ると，樹木管理につい ては，構成団体に造園系団体を含む場合と含まない場合を比較す ると，「造園系団体を含む」場合では「直営」が $63.8 \%$ と比較的 高く,「委託」が $13.8 \%$ と低いのに対して，「造園系団体を含まな い」では「委託」の方が $53.8 \%$ と高く，「造園系団体を含む」場 合には指定管理者の直営業務として行われる傾向が強いことが分 かる。樹林管理についても，「造園系団体を含む」場合では「直営」 が $62.1 \%$ と高く,「委託」が $6.9 \%$ と非常に低いのに対して,「造 園系団体を含まない」場合では「直営」が $30.8 \%$ に半減する。芝 生管理，草花管理，草地管理もほぼ同様の傾向を示し，植物管理 に関しては「造園系団体を含む」場合には直営が多くなり，植物 管理に対する造園系団体の一定の技術的蓄積が窅える。

（ii）植物管理における協働ボランティアの参画状況

植物管理における協働ボランティアの参画状況（図－2）を見る と，樹木管理，樹林管理，芝生管理については，全体で「協働なし」 が非常に高く，「造園系団体を含む」場合と「造園系団体を含まない」 場合で目立った差異はない。しかし，草花管理については「協働 あり」が比較的高くなっており，「造園系団体を含む」場合では「協 働あり」が $44.8 \%$ と半数に迫っている。一方, 「造園系団体を含 まない」場合では「協働あり」が $19.2 \%$ と比較的低く，草花管理 を通じた協働を推進する上で造園系団体が一定の役割を果たして いることが椝える。草地管理については「造園系団体を含む」場 合では「協働あり」が $10.3 \%$ ，「造園系団体を含まない」場合で は「協働あり」が $19.2 \%$ と造園系団体を含まない」場合の方が ボランティアとの協働がある指定管理者の比率が若干高かった。

（iii）運営管理における協働ボランティアの参画状沉

運営管理における協働ボランティアの参画状況（図一 3 ）を見

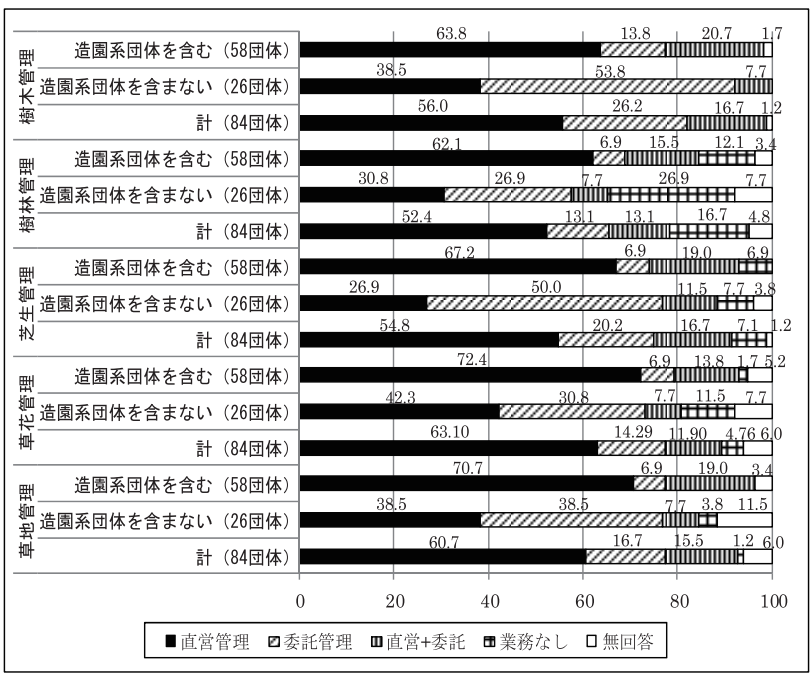

図一1 植物管理実施主体の状況 


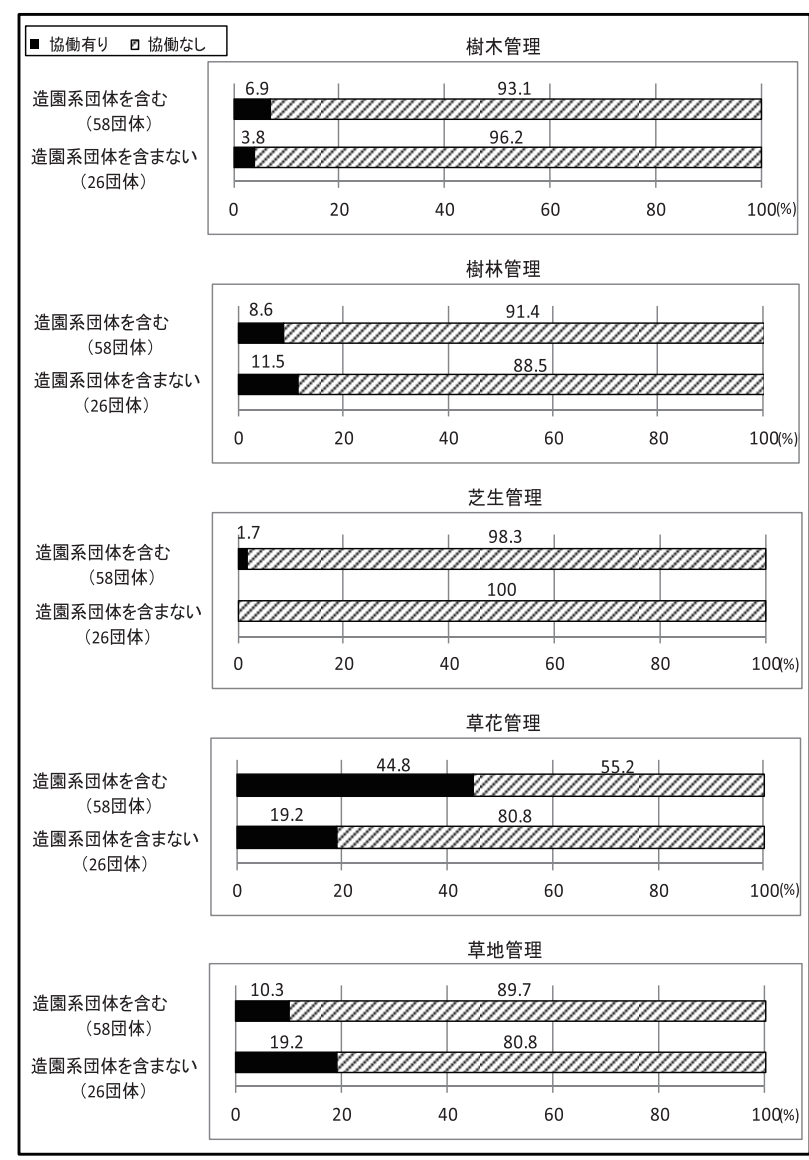

図－２植物管理ける協働ボランティアの参画状況

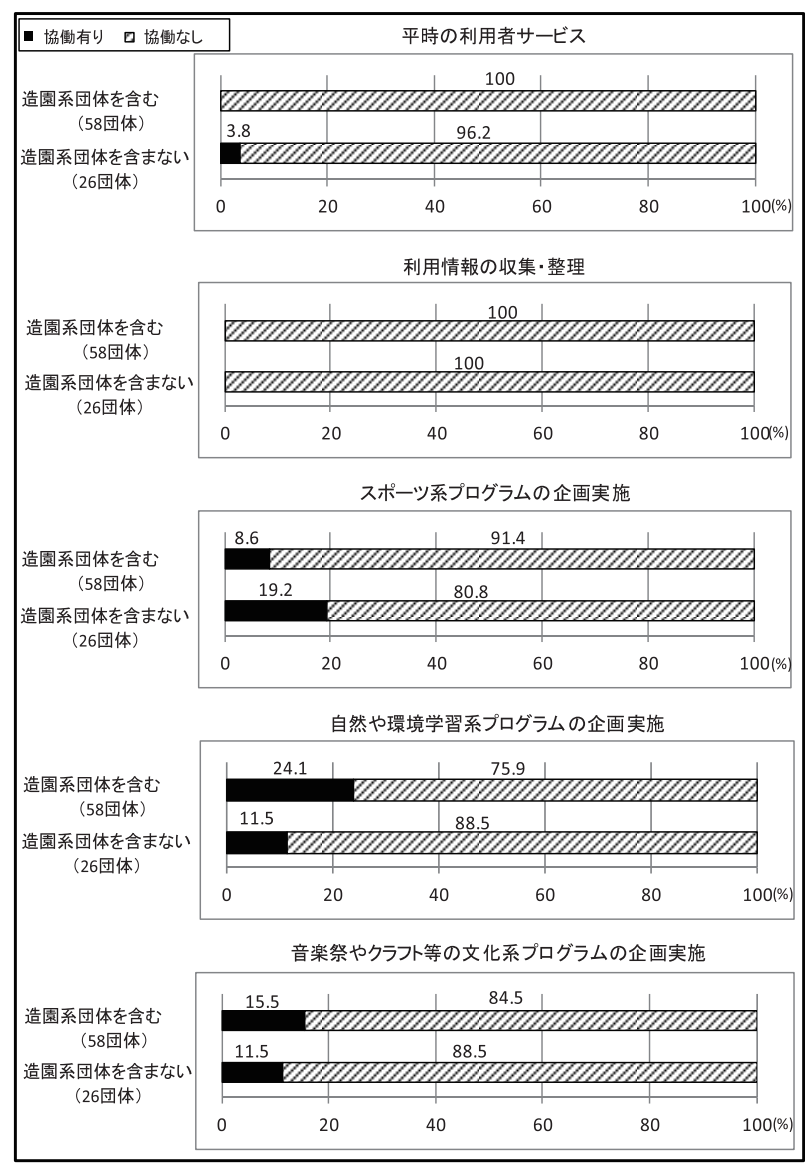

図－3 運営管理における協働ボランティアの参画状況
ると，平時の利用者サービスと利用に係る情報の収集・整理に関 しては，ほとんどすべての対象公園でボランティアとの協働が成 立していない。一方，音楽祭やクラフト等の文化系プログラムの 企画・実施における協働ボランティアの参画状況に関しては，「造 園系団体を含む」場合では「協働あり」が $15.5 \%$ ，「造園系団体 を含まない」場合でも「協働あり」が $11.5 \%$ 之共に一定程度の協 働が行われていることがわかる。また，スポーツ系プログラムの 企画・実施に関しては，「造園系団体を含む」場合では「協働あり」 が 58 団体中 5 団体，8.6\%であるのに対し，「造園系団体を含ま ない」場合では「協働あり」が 26 団体中 5 団体，19.2\% とその 占める割合が高く，そのうちスポーツ振興系財団法人を含む団体 が 2 団体を占めている。一方, 自然や環境学習系プログラムの企 画・実施に関しては，「造園系団体を含む」場合では「協働あり」 が 24.1\%，「造園系団体を含まない」場合では「協働あり」が 11.5\%であり, 自然や環境学習を通じた市民協働に関して造園系 団体の一定の技術的蓄積が窥える。

\section{（3）植物管理の目的と目標像の設定期間}

\section{(i ) 植物管理の目的}

植物管理の目的（図-4）は, (1)植物の成長抑制, 成長促進, (2)植物の病虫害防除，(3)植物の施肥や排水等の植栽基盤改良，(4) 植物の形態コントロールによる目標景観の創出, (5)利用時の安全 確保に大別して整理し，5項目から管理目的としているもの全て を選択記入するよう求めた。

樹木管理を行う際の管理目的をみると，「造園系団体を含む」 と「造園系団体を含まない」に共通して,「利用時の安全確保」 が約 9 割と最も高く, 次いで「植物の病虫害防除」が約 8 割,「植 物の成長抑制, 成長促進」と「植物の施肥や排水等の植栽基盤改 良」が約 6 割と続いている。また, 「植物の成長抑制, 成長促進」 と「植物の形態コントロールによる目標景観の創出」に対しては, 「造園系団体を含む」場合は「造園系団体を含まない」場合より もいずれも 2 割程度高くなっている。樹林管理をみると，「造園 系団体を含む」場合は全ての項目で「造園系団体を含まない」場 合を上回っている。芝生管理と草花管理，草地管理をみると，「植 物の成長抑制, 成長促進」と「植物の病虫害防除」に対しては, 「造園系団体を含む」と「造園系団体を含まない」でほぼ同等か, もしくは若干「造園系団体を含まない」場合が高いのに対して， 「植物の形態コントロールによる目標景観の創出」では,「造園系 団体を含む」場合の方が高く，特に芝生管理と草花管理でその傾 向は顕著である。また，「植物の施肥や排水等の植栽基盤改良」 之「利用時の安全確保」では，両者で大きな差異が見られない。

従って，樹木管理及び樹林管理においては「造園系団体を含む」 方がいずれの項目に対しても管理目的として位置づけている指定 管理者の比率が「造園系団体を含まない」場合より高く，特に樹

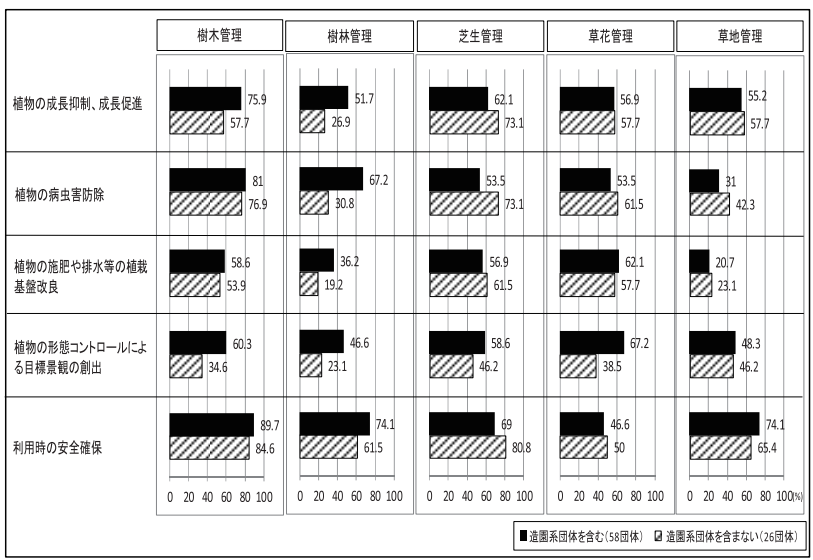

図 -4 植物管理の目的 
林管理ではその傾向が顕著であり，樹木管理及び樹林管理におい てょり配慮している指定管理者が多いと推察される。また,「造 園系団体を含む」場合の方が樹木から草地管理に至るまで, 景観 創出を意識した管理を行い, 都市公園の質を決定する重要な要因 の一つとなる景観に対してもより配慮していると言える。

\section{(ii ) 植物管理目標像の設定期間}

植物管理の目標像の設定期間（図－5）は，(1)指定管理期間を 越えた長期的目標像を持って管理している，(2)指定管理期間内の 目標像を持って管理している, (3)一年間毎の目標像を持って管理 している, (4)必要性が発生した時だけ管理している, に大別して 整理し，4 項目から該当する項目全てを選択記入するよう求めた。

樹木管理を行う際の管理目標像の設定期間をみると，「造園系 団体を含む」場合では，「指定管理期間を越えた長期的目標像を 持って管理している」という回答が約 6 割と最も高く,「指定管 理期間内の目標像を持って管理している」,「一年間毎の目標像を 持って管理している」が約 4 割と続き,「必要性が発生した時に だけ管理している」が約 2 割と低くなっている。一方,「造園系 団体を含まない」場合では，「指定管理期間を越えた長期的目標 像を持って管理している」が約 4 割強に留まり，「一年間毎の目 標像を持って管理している」が約 4 割, 「必要性が発生した時に だけ管理している」が約 3 割,「指定管理期間内の目標像を持っ て管理している」が 2 割強となっている。樹林管理をみても，樹 木管理とほぼ同様の傾向を示し，「指定管理期間を越えた長期的 目標像を持って管理している」という項目ではこの項目を設定期 間としている指定管理者の比率は「造園系団体を含む」場合の方 が「造園系団体を含まない」場合よりもより差が大きい。芝生管 理と草地管理をみると，「指定管理期間を越えた長期的目標像を 持って管理している」では，「造園系団体を含む」場合の方が若 干多いものの，その他の期間に関しては大きな差異はない。一方， 草花管理をみると，「指定管理期間内の目標像を持って管理して いる」が「造園系団体を含む」場合は「造園系団体を含まない」 場合より 2 割程度高いことが特徵である。

従って，樹木管理から草地管理に至るまで「造園系団体を含む」 場合の方が中長期的期間を設定して管理している指定管理者の比 率が高く, 長期的目標像をもつ管理者が多いと言える。特に樹木 管理と樹林管理ではその傾向が顕著であることが明らかとなった。

\section{（4）植物管理を行う際の課題}

( i ) 植物管理における技術面の課題

植物管理を行う際の技術面の課題 (図一 - 6) は, (1)植物の成長 抑制，成長促進に関わる技術，(2)植物の病虫害防除に対する技術， (3)植物の施肥や排水等植栽基盤改良に関わる技術, (4)目標景観の デザインに関わる技術，(5)利用時の安全性の確保に関わる技術, に大別して整理し， 5 項目から技術面の課題として認識している

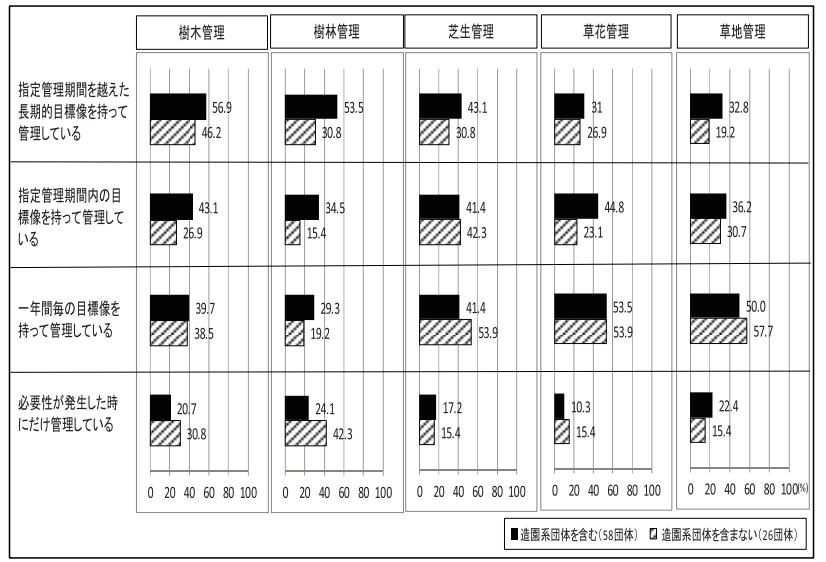

図- 5 植物管理の目標像の設定期間
項目全てを選択記入するよう求めた。

「植物の成長抑制，成長促進に関わる技術」をみると，樹木管 理，樹林管理については「造園系団体を含む」場合と「造園系団 体を含まない」場合は共に約 4 割となり，両者の差があまりない。 一方，芝生管理と草花管理，草地管理については「造園系団体を 含まない」場合は「造園系団体を含む」場合より 1 割から 2 割程 度高く，技術面の課題を認識している指定管理者の比率が高い。 「植物の病虫害防除に対する技術」についても同様の傾向を示す。 「植物の施肥や排水等植栽基盤改良に関わる技術」をみると，樹 林管理で若干の差異が認められるものの両者に大きな差異はない。 一方，「目標景観のデザインに関わる技術」をみると，樹木管理， 草花管理については「造園系団体を含む」場合と「造園系団体を 含まない」場合は共に約 4 割となっているが，樹林管理と草地管 理では「造園系団体を含む」場合が約 4 割, 「造園系団体を含ま ない」場合が約 3 割となっており，「造園系団体を含む」場合の 方が景観形成に対して課題認識している割合が高い。「利用時の 安全性の確保に関わる技術」をみると，樹林管理，草花管理，草 地管理では大きな差異は認められない。

従って，芝生管理，草花管理，草地管理に関しては「造園系団 体を含まない」場合は「植物の成長抑制, 成長促進に関わる技術」, 「植物の病虫害防除に対する技術」，「植物の施肥や排水等植栽基 盤改良に関わる技術」のいずれの項目に対しても「造園系団体を 含む」場合と比較して技術面の課題があると認識している指定管 理者の比率が高い。一方，「造園系団体を含む」場合は，これら の項目に対して課題があると認識している指定管理者の比率は低 く, 樹林管理や草地管理において景観形成に対する課題を認識し ている指定管理者の此率が高いことが明らかとなった。このこと から，課題があると認識されていない場合，技術力が十分な水準 に達していないことによるのか, 技術力が十分にあって目標とす る植物管理のレベルが高いことによるのか，がこのアンケート調 査の設問では明確にならなかったが，「造園系団体を含む」場合は， ある一定の植物管理に関する技術を持っていることから植物の育 成管理における技術面の課題を認識している指定管理者が少なく, 目標景観のデザインに対してはさらに高度な植物管理が目指され ているために樹林管理や草地管理で課題があると認識している指 定管理者が多いのではないか，と推察される。

（ii）植物管理における利用調整面の課題

植物管理における利用調整面の課題（図－7）は，(1)植物養生 期間と利用制限との関係，(2)薬剂散布と利用制限との関係，(3)生 物生息之利用制限との関係，に大別して整理し，3 項目から利用 調整面の課題として認識している項目全てを記入するよう求めた。

「植物養生期間と利用制限との関係」に対しては, 芝生管理で

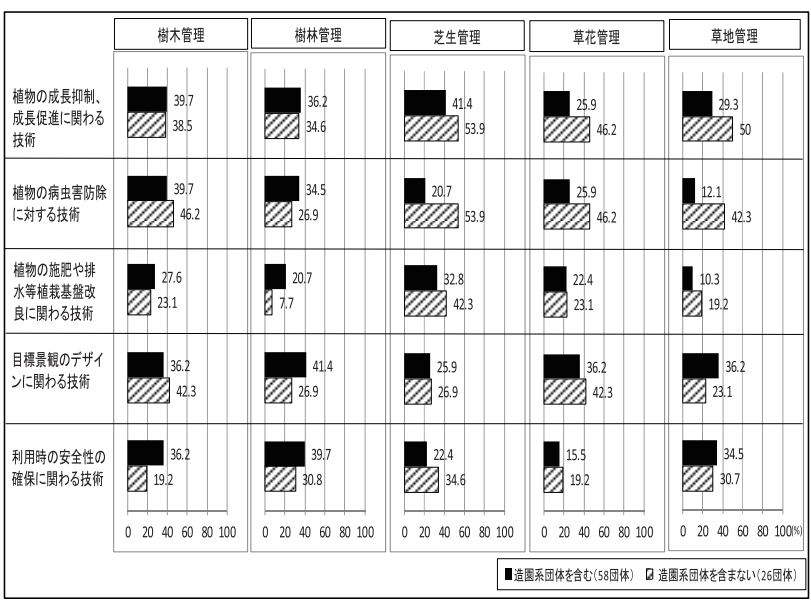

図一 6 植物管理における技術面の課題 


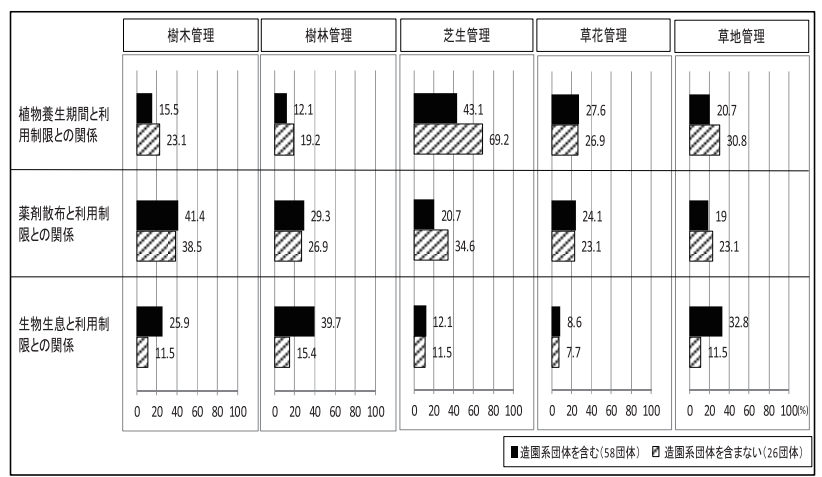

図-7 植物管理における利用調整面の課題

は課題としては認識している指定管理者が「造園系団体を含む」 場合が約 4 割であるのに対して,「造園系団体を含まない」場合 では約 7 割と非常に高くなっている。「薬剤散布と利用制限との 関係」でも，芝生管理では「造園系団体を含む」場合が約 2 割に 対して，「造園系団体を含まない」場合が約 3 割と高い。一方，「生 物生息と利用制限との関係」をみると, 樹木管理と樹林管理, 草 地管理については「造園系団体を含む」場合の方が「造園系団体 を含まない」場合より 1 割〜 2 割程度高い。

従って, 樹木管理と樹林管理, 草地管理では「造園系団体を含 む」場合には生物生息への配慮を課題として認識している指定管 理者の比率が高い。一方，芝生管理では「造園系団体を含まない」 場合には養生期間を意識した利用調整を課題として認識されてい る指定管理者の比率が高いといった差異が確認できる。このこと から，「造園系団体を含む」場合には，適切な芝生管理技術を有 している指定管理者が多いために芝生の養成期間及び薬剂散布と 利用制限との関係に対して課題があると認識している管理者が少 なく, 樹木管理, 樹林管理及び草地管理において生物の生育に配 慮したより高度な植物管理を目標としているために生物生息と利 用調整との関係に対して課題があると認識している指定管理者が 多いのではないかと推察される。

\section{4.まとめ}

\section{（1）指定管理者の構成団体}

都市公園への指定管理者制度導入後, 約 10 年が過ぎたが, 都 道府県の広域公園の指定管理者では, 制度導入以前より公園管理 に携わってきた公園管理系の財団法人が現在でも指定管理者構成 団体全体の 4 割を占め最も多いものの, 造園施設建設系の民間会 社も約 3 割を占めるようになっていることやビルメンテナンス系 の民間会社が 1 割程度を占めるなど, 様々な民間会社が参入して いることが明らかとなった。特に, 造園系以外の団体が指定管理 者となっている都道府県営の広域公園は 3 割強を占めることが明 らかとなった。

\section{（2）協働ボランティアの参画状況}

協働ボランティアの参画では, 植物管理, 運営管理とともに一 部のプログラムに限られていることが明らかとなった。植物管理 における協働ボランティアの参画状況では，草花管理については， 「協働あり」が比較的高くなっている。「造園系団体を含む」場合 では「協働あり」が半数近くなっており，「造園系団体を含まない」 場合と比較して, 比率が高いことが明らかとなった。運営管理に おける協㗢ボランティアの参画状況では，「造園系団体を含む」 場合には, 自然や環境学習系プログラムの企画・実施に関する協 働などが,「造園系団体を含まない」場合よりも促進されている ことが明らかとなった。一方，「造園系団体を含まない」場合に は特にスポーツ系プログラムの企画・実施に関する協働が「造園 系団体を含む」場合よりも若干促進されているといった実態も明
らかとなった。このことから「造園系団体を含む」場合は，草花 や自然学習プログラムに関する協働が促進されている。一方，「造 園系団体を含まない」場合はスポーツ系プログラムに関する協働 が促進されており，指定管理者の構成団体の違いによって協働ボ ランティアの参画状況の特性が大きく異なることが明らかとなった。

\section{（3）植物管理の実態}

植物管理の実態を整理すると，樹木管理から草地管理に至る植 物管理全般に関しては「造園系団体を含む」場合には直営が多く, 含まない場合は委託が多くなる傾向にあることが明らかとなり， 植物管理に対する造園系団体の一定の技術的蓄積の発揮が窺えた。

このような状況の中で，植物管理における目的や目標像の設定 期間, 技術面の課題, 利用調整面の課題をみると, 特に, 植物管 理における目的に関しては，樹木管理及び樹林管理において「造 園系団体を含む」場合は，5つの項目すべてに対して管理目的と して位置づけている指定管理者の比率が「造園系団体を含まない」 場合より高く，特に樹林管理に対してはその傾向が顕著であった。 管理目標像の設定期間に関しては，都市公園の骨格となる樹木や 樹林の管理において，「造園系団体を含む」場合の方が，「造園系 団体を含まない」場合に比べて，ょり中長期的な目標像の設定を 行っていることが明らかになった。

植物管理における技術面の課題に関しては，芝生管理，草花管 理，草地管理においては，「造園系団体を含まない」場合には植 物の成長抑制や成長促進，病虫害防除，施肥や排水等植栽基盤改 良といった基礎的な植物管理に関わる技術の課題があると認識し ている指定管理者の比率が高く，一方，樹林管理や草地管理にお いては，「造園系団体を含む」場合の方が，基礎的な技術ではな く景観形成に対する課題といったより高度な植物管理を認識して いる指定管理者の比率が高いことが明らかとなった。植物管理に おける利用調整面の課題については，樹木管理，樹林管理，草地 管理においては「造園系団体を含む」場合の方が，生物生息への 配慮を課題として認識している指定管理者の比率が高く, 芝生管 理においては「造園系団体を含まない」場合の方が，養生期間と いった基礎的な利用調整を課題として認識している指定管理者の 比率が高いことが明らかとなった。このことから，「造園系団体 を含む」場合は，植物の成長抑制などの植物管理における基礎的 な管理技術に対する課題が少なく，景観形成といった高度な技術 的課題を保有するとともに，生物生息への配慮といった複雑な利 用調整面の課題について認識していることが明らかとなった。

\section{補注及び引用文献}

1 ）増田昇（2010）：公園の価值を高める指定管理者の評価と指導：公園 緑地 71(4)，10-12，図巻頭 1p，2010-11 日本公園緑地協会

2 ）塚田伸也・湯沢昭（2008）：都市公園に打ける指定管理者の選考基準 の現状之評価構造の分析：日本建築学会計画系論文集, 73(631), 1923-1928

3 ）浦田興・平田富士男（2007）：都市公園における民間指定管理者と市 民グループの関係の状況及びよりょい関係構築に必要な取り組みの方 向性：都市計画論文集，42(3)，175-180

4 ）大瀧英知・三宅諭（2007）：指定管理者制度による都市公園の管理運 営における協働事業の実態とあり方一御所湖広域公園之花巻広域公園 を事例として一：都市公園論文集，42(3)，181-186

5 ) 前田博 (2009)：指定管理者制度導入前後の公園利用者満足度調查比 較にみる制度導入の影響に関する考察：ランドスケープ研究，72(5), $591-594$

6 ）李婷・下村泰彦・加我宏之・増田昇（2011）：都道府県営の広域公園 における指定管理者制度の運営課題に関する研究：環境情報科学論文 集 $25,443-448$

7 ) 李婷・下村泰彦・加我宏之・岡田えりか・増田昇 (2012)：大阪府営 公園大泉緑地を事例とする樹林管理と林内利用評価に関する研究：環 境情報科学論文集 $26,345-350$

(2013.4.30 受付, 2014.8.21 受理) 